\title{
Innowacyjne nawierzchnie wodoprzepuszczalne \\ - możliwości zastosowania w historycznych ogrodach i parkach publicznych
}

Innovative water permeable pavements

- the praxis of using

in historical public gardens and parks

\section{Streszczenie}

W artykule przedstawiono możliwości zastosowania innowacyjnych nawierzchni wodoprzepuszczalnych (zbudowanych z materiałów naturalnych lub naturalnych zespojonych żywicą epoksydową) w parkach publicznych powstałych w XIX wieku. Określono je w kontekście uwarunkowań konserwatorskich związanych z ochroną wartości historycznych parków, a także konieczności adaptacji tych obiektów do nowych funkcji, wynikających z narastających potrzeb społecznych. Ocenę innowacyjnych rozwiązań w zakresie stosowania tych nawierzchni przedstawiono w odniesieniu do aspektów funkcjonalnych, technicznych i ekonomicznych, estetycznych oraz przyrodniczych.

Słowa kluczowe: nawierzchnia, nawierzchnia wodoprzepuszczalna, konserwacja, park publiczny

\begin{abstract}
The paper summarizes an innovative water permeable pavements (consist of natural aggregates or natural aggregates joined by epoxy resin) and the possibilities of their application to public parks laid out in the 19th century. They were characterized in the context of conservation rules related to protection of historical values of parks and connected with the process of their adaptation to the new functions resulted from the increase of social needs. The evaluation of innovative pavements includes functional, technical, economic, aesthetic and environmental aspects.
\end{abstract}

Keywords: pavement, water-premeable pavement, conservation, public park 


\section{WSTĘP}

Drogi tworzące określone układy (regularne, swobodne lub łączące obie te formy), a także ich nawierzchnie, wykonane z określonych materiałów i przy użyciu charakterystycznych dla danej epoki rozwiązań technicznych, stanowią integralną część kompozycji dzieła ogrodowego. W zależności od czasu powstania danego ogrodu czy parku oraz ich przeznaczenia (obiekty prywatne lub publiczne), układy drogowe pełniły określone funkcje związane ze spełnieniem potrzeb ruchu, a ich realizację wspomagały nawierzchnie wykonane z odpowiednio dobranych materiałów. W przypadku publicznych założeń ogrodowych - przekształconych z obiektów rezydencjonalnych, jak i nowo tworzonych w XIX wieku - problematyka konserwacji, ale także rewaloryzacji i adaptacji ich nawierzchni do nowych funkcji jest zagadnieniem złożonym. Uwarunkowana jest z jednej strony koniecznością zachowania wartości zabytkowych obiektów, jakimi są w większości przypadków historyczne ogrody i parki publiczne przetrwałe do czasów obecnych. Z drugiej strony przemiany w zakresie funkcjonowania tych obiektów, związane z ich rozwojem w kolejnych latach, a także potrzebą przystosowania do potrzeb i oczekiwań kolejnych pokoleń użytkowników, uwarunkowane są historycznie i stanowią jeden z charakterystycznych etapów przekształceń publicznych założeń ogrodowych, gwarantujących ciągłość ich istnienia. Sytuacja ta wymaga zatem poszukiwania takich rozwiązań w zakresie kształtowania nawierzchni w historycznych ogrodach i parkach publicznych, które pozwolą na realizację ich nowych zadań bez utraty posiadanych przez nie wartości. Pomocne w tym mogą być technologie wykorzystujące innowacyjne rozwiązania w zakresie nawierzchni, których zastosowanie pozwoli na ich jak najbardziej pełne dopasowanie do charakteru dawnych założeń ogrodowych pod względem stosowanego materiału, nawiązując do cech uwarunkowanych historycznie, walorów ozdobnych i plastycznych, ale także ułatwi ich użytkowanie, podnosząc trwałość i ograniczając koszty eksploatacji, utrzymania i konserwacji.

\section{CEL I ZAKRES OPRACOWANIA}

Niniejsze opracowanie dotyczy problematyki konserwacji, a także rewaloryzacji i adaptacji do nowych potrzeb nawierzchni historycznych ogrodów i parków. Przedstawia zagadnienia związane ze stosowaniem nowych rozwiązań w kształtowaniu tych szczególnie ważnych elementów układu drogowego. Celem jest wskazanie możliwości zastosowania wybranych rodzajów nawierzchni wodoprzepuszczalnych - mineralnych, ale również mineralno-żywicznych - jako alternatywnych rozwiązań dla nawierzchni żwirowych powszechnie stosowanych w obiektach XIX-wiecznych, ale nie spełniających współczesnych wymogów względem realizacji potrzeb ruchu.

Zagadnienia dotyczące możliwości zastosowania nowych rozwiązań dla nawierzchni parkowych przedstawiono w odniesieniu do wybranej grupy historycznych założeń ogrodowych, 
jaką stanowią parki publiczne XIX wieku zachowane do dziś - zarówno te powstałe z przekształcenia założeń rezydencjonalnych w obiekty ogólnodostępne, jak i nowo założone w tym okresie. Badania oparte o przegląd literatury przedmiotu pozwoliły na rozpoznanie uwarunkowań historycznych stosowania typowych nawierzchni charakterystycznych dla parków publicznych w XIX wieku, a następnie prześledzenie kierunków i wiodących tendencji w zakresie przemian w stosowaniu charakterystycznych materiałów w kolejnych latach ich istnienia aż do chwili obecnej. Szczególną uwagę poświęcono rozpoznaniu uwarunkowań związanych z potrzebą zmian w stosowaniu nawierzchni w parkach publicznych tego okresu w procesie ich wieloletniej adaptacji do nowych funkcji, wynikającej przede wszystkim ze zmiany intensywności ich użytkowania. Przedstawiono skutki stosowania niewłaściwych rozwiązań, stanowiące podstawę do podjęcia obecnie działań służących przywróceniu tym obiektom ich dawnych wartości. Analizie i ocenie poddano cechy stosowanych obecnie nawierzchni mineralnych oraz mineralno-żywicznych, wskazując możliwości ich zastosowania w historycznych parkach i ogrodach publicznych. Poparto je przykładami realizacji pochodzących z kilku ostatnich lat w zakresie wprowadzania tych nowych rodzajów nawierzchni w wybranych historycznych parkach publicznych w Warszawie.

\section{NAWIERZCHNIE HISTORYCZNYCH PARKÓW PUBLICZNYCH - PRZEMIANY}

Układ drogowy - pełniący w ogrodzie lub parku publicznym funkcje użytkowo-komunikacyjne oraz kompozycyjne - jest wynikiem jego świadomego ukształtowania przez człowieka, zgodnie z zasadami przyjętymi dla stylu bądź nurtu obowiązującego w danym okresie historycznym. Nawierzchnie stanowią integralny element dróg. Były i są kształtowane przy wykorzystaniu dostępnych rozwiązań technicznych oraz za pomocą określonych materiałów charakterystycznych dla danej epoki. W kolejnych latach istnienia publicznych ogrodów i parków, począwszy od XIX wieku, również ich nawierzchnie podlegały określonym przemianom.

Ogrody i parki publiczne tworzone w XIX wieku, zarówno przekształcane z założeń rezydencjonalnych, jak i nowo tworzone, przyjmowały w większości przypadków cechy rozwiązań krajobrazowych. Ich układ drogowy podlegał w kolejnych okresach rozwojowi. W pierwszych założeniach tego rodzaju, powstających w początku XIX wieku, stosowano rozwiązania nawiązujące do tych stosowanych w założeniach rezydencjonalnych, łączące elementy regularne (będące osnową danego założenia) z krajobrazowymi, stanowiącymi ich uzupełnienie. W połowie XIX wieku i w latach kolejnych układ drogowy ogrodów i parków publicznych przyjmował już formę znacznie bardziej złożoną, zdominowaną przez elementy krajobrazowe jedynie uzupełnione przez regularne (prosta aleja, place wypoczynkowe) ${ }^{1}$. W rozbudowanym układzie płynnie prowadzonych dróg uwzględniano ich hierarchię - podział na drogi główne oraz boczne, bardziej kameralne ${ }^{2}$. Dominującą formą wypoczynku był spacer, a ze względu na małe obciążenie dróg powszechnie stosowano na nich nawierzchnie ziemne i żwirowe, 
a tylko w niektórych miejscach - w sąsiedztwie reprezentacyjnych budowli ogrodowych lub strefach wymagających zapewnienia dojazdu - stosowano nawierzchnie kamienne. Wprowadzanie nawierzchni z materiałów naturalnych pozwalało na łatwe dopasowanie ich do płynnego przebiegu dróg parkowych i nie wymagały one stosowania obrzeży ${ }^{3}$. Jednocześnie były stosunkowo łatwe w realizacji i utrzymaniu - starano się wykorzystywać podstawowy materiał występujący na danym terenie, a przy tym zgodny z duchem miejsca. Dodatkowym atutem był naturalny wygląd nawierzchni, zgodny z założeniami rozwiązań krajobrazowych, opartych o wykorzystanie elementów wywodzących się z przyrody i nawiązujących do niej. Zasady te utrzymano do połowy XX wieku, łącząc je z procesem usprawniania układu komunikacji w obiektach publicznych i adaptowaniem nawierzchni do nowych potrzeb społecznych związanych z rozwojem programu parków.

Po zakończeniu II wojny światowej, w okresie odbudowy zniszczonych miast, zaobserwować można znaczny wzrost w zakresie ogólnych wymagań komunikacyjnych, będących następstwem znacznego nasilenia ruchu, ale również potrzebę mechanizacji prac drogowych służących ograniczeniu kosztów realizacji. Czynnikiem nadrzędnym stały się komfort i bezpieczeństwo użytkowania dróg. W efekcie tych zmian, zwłaszcza od lat 50. XX wieku, na większości ulic miejskich, ale także chodników i ciągów spacerowych, powszechnie zaczęto stosować nawierzchnie z mas mineralno-bitumicznych, w tym asfaltowe. Wpłynęło to negatywnie na „pejzaż” podłogi wielu miast, który „zdominowała płaszczyzna szara lub czarna, gładka, pozbawiona elementów zróżnicowania fakturowego, stosunkowo szybko ulegająca destrukcji”" Inwazja nawierzchni bitumicznych wprowadzanych na szeroką skalę, zanim spotkała się z głosami krytycznymi, wskazującymi na utratę wartości nawierzchni nieasfaltowych ${ }^{5}$, również znalazła zastosowanie w nowo tworzonych parkach publicznych ${ }^{6}$, a co gorsza - niestety także w ogrodach i parkach historycznych. Wiele nawierzchni ziemnych, żwirowych, jak i wykonanych z kostki kamiennej oraz innych materiałów, wprowadzonych w okresie powstania publicznych założeń ogrodowych, zamieniono na bitumiczne - wygodne dla pieszych i wytrzymałe, ale jakże ingerujące w zabytkową substancję tych obiektów. Materiał ten był niezgodny z ich charakterystycznymi cechami uwarunkowanymi historycznie, obniżał walory artystyczne i wizualne, a jego zastosowanie wpłynęło w wielu przypadkach na destrukcję innych elementów kompozycji poza układem drogowym. Skutki takich działań obserwować możemy do dziś w wielu ogrodach i parkach publicznych. Niechlubnym przykładem jest Ogród Saski w Warszawie, którego aleja główna, pokryta asfaltem kilka dekad temu, nie doczekała się rewaloryzacji do dziś, a zatopione w tej nieprzepuszczalnej nawierzchni wiekowe kasztanowce, budujące oś kompozycyjną ogrodu, w szybkim tempie obumierają (il. 1). Z wymienionych tu względów nawierzchni takich powinno się w parkach historycznych unikać, a ewentualne do ich dopuszczenia może dojść wyłącznie w wyjątkowych przypadkach ${ }^{7}$. Kolejne lata XX wieku to również dalsze zmiany związane z wprowadzaniem różnorodnych nawierzchni w historycznych ogrodach i parkach publicznych, będące oznaką braku dbałości o te obiekty i braku właściwie prowadzonych zabiegów służących 
ochronie ich wartości. Nawet w jednym obiekcie można dziś odnaleźć - oprócz nawierzchni asfaltowych, ziemnych i żwirowych - także płyty i kostki betonowe, które nagminnie stosuje się do utwardzenia licznie powstających przedeptów. Za przykład może posłużyć Park im. gen. J. Sowińskiego w Warszawie, powstały w latach 30. XX wieku (il. 2). Działania takie uwarunkowane są zarówno brakiem funduszy na utrzymanie parków (w tym potrzebą ograniczania kosztów realizacji, remontów i utrzymania nawierzchni), korzystaniem z powszechnie dostępnych materiałów, jak i unifikacją stosowanych rozwiązań bez dbałości o jakość i detal. Zabiegi takie, związane z odchodzeniem od nawiązań do historycznych materiałów, i eliminowanie elementów charakterystycznych, stosowanych w kształtowaniu nawierzchni założeń ogrodowych, stanowią zagrożenie dla historycznych ogrodów i parków publicznych tym bardziej, że złe decyzje są w przypadku tych obiektów niestety utrwalane, a brak reakcji ze strony zarządzających obiektami na przestrzeni wielu już lat tylko pogłębia destrukcję.

Nadmierna i nieuzasadniona dowolność zmian w zakresie wprowadzanych nawierzchni w historycznych ogrodach i parkach publicznych, zwłaszcza w 2 połowie XX wieku, spowodowała utratę wartości zabytkowych wielu obiektów. Wymaga zatem wykluczenia takiego postępowania dla uniknięcia nawarstwiania się zjawisk negatywnych, ale też jak najszybszego przeciwdziałania już istniejącym niekorzystnym zmianom.

\section{WSPÓŁCZESNE KIERUNKI REWALORYZACJI I ADAPTACJI NAWIERZCHNI}

Problematyka stosowania określonych nawierzchni w zabytkowych założeniach ogrodowych, a zwłaszcza w historycznych ogrodach i parkach publicznych, wymaga bardzo szczegółowego podejścia. Z jednej strony wynika ono z potrzeby zachowania ich walorów historycznych, autentyczności ${ }^{8}$ tych obiektów, gdyż nawierzchnie ogrodowe, pozostające w wielu przypadkach częścią zabytkowego układu, podlegają ochronie ${ }^{9}$. Są jednocześnie - zwłaszcza te gruntowe i żwirowe - jednym z elementów kompozycji założeń ogrodowych charakteryzujących się ograniczoną trwałością, są narażone na wiele zniekształceń uwarunkowanych zarówno upływem czasu, jak i wpływem czynników atmosferycznych. Z drugiej strony, w wielu przypadkach wymagają dostosowania do wymogów czasów współczesnych w zakresie sprostania narastającym potrzebom ruchu, które odbiegają od ich pierwotnego sposobu użytkowania. Są więc narażone na zmiany wynikające również ze zmiany sposobu i intensywności ich użytkowania ${ }^{10}$. Warto w tym miejscu podkreślić, iż w przypadku publicznych założeń ogrodowych o długiej historii, proces adaptacji ich poszczególnych elementów kompozycji do nowych zadań i funkcji jest bezpośrednio uwarunkowany narastaniem oczekiwań społecznych. Dotyczą one zarówno potrzeb w zakresie wzbogacania dotychczasowej formy przestrzennej założeń ogrodowych, jak i poszerzania ich dotychczasowej, już niewystarczającej oferty programowej. Uczestniczy w tym procesie także układ drogowy wraz z nawierzchniami. Ta historycznie uwarunkowana zależność pozwoliła na przetrwanie i specjalizowanie 
publicznych założeń ogrodowych do nowych funkcji, a w wielu przypadkach zadecydowała o ich przetrwaniu. Świadczyły zatem o ciągłości ich rozwoju, a przez to o istnieniu ${ }^{11}$.

Mając na uwadze wymienione uwarunkowania, konsekwentnie prowadzona konserwacja, obejmująca zabezpieczenie zabytkowego układu drogowego i nawierzchni, wskazana jest w przypadku obiektów o najwyższej randze, wymagających bezwzględnego zachowania ich wartości. Największym problemem dla tych obiektów jest znaczny wzrost frekwencji użytkowników, powiązany ze zmianą sposobu ich użytkowania, wpływający na destrukcję całości układu ${ }^{12}$. Jednak w większości przypadków - zarówno w procesie przekształcania rezydencjonalnych założeń ogrodowych w publiczne, jak i rozwoju publicznych założeń ogrodowych w kolejnych latach ich istnienia - zmiana sposobu użytkowania na przestrzeni lat wymagała adaptacji zarówno ich układu drogowego, jak i nawierzchni. Również obecnie wszelkie ograniczenia w zakresie dostępności ogrodów i parków publicznych dla użytkowników stanowią zaprzeczenie ich wiodącej roli jako obiektów ogólnie dostępnych, które z założenia powinny być otwarte dla każdego bez ograniczeń. Im większe następują więc zmiany, uwarunkowane koniecznością dostosowania tych obiektów do nowych potrzeb społecznych i nasilającej się intensywności użytkowania, tym bardziej wzrasta również konieczność ich adaptacji do nowych funkcji ${ }^{13}$.

W przypadku historycznych ogrodów i parków publicznych proces ich dostosowania do nowych wymogów może wiązać się zarówno z częściową, jak i całkowitą wymianą nawierzchni. Wprowadzanie rozwiązań innowacyjnych powinno jednak w jak najszerszym zakresie naśladować pod względem materiałów te stosowane dawniej, nawiązując do uwarunkowanych historycznie cech charakterystycznych danego założenia, zgodnie z okresem ich powstania. Proces ten - uwzględniający nawiązanie do przeszłości oraz pogodzenie z niezbędnymi funkcjami nowo wprowadzonych nawierzchni i konieczność sprostania stawianym im dzisiaj coraz większym wymaganiom - powinien odbywać się w imię „twórczej kontynuacji tradycji"14. Omawiając kryteria doboru nawierzchni w historycznych ogrodach i parkach publicznych, wskazuje się zatem na potrzebę pogodzenia działań służących realizacji potrzeb konserwatorskich (konieczność poszanowania zasad kompozycji, uwzględnienie cech charakterystycznych ogrodu, kolorystyki, faktury itd.), społecznych (poprawa dostępności obiektów, dostosowanie do zwiększającej się intensywności użytkowania i nowych funkcji, funkcjonalność, ale też podnoszenie walorów estetycznych), technicznych (dostosowanie do charakteru ruchu i uwarunkowań terenowych, zwiększenie wytrzymałości na obciążenia uwarunkowane ruchem, zużycie i odkształcenia, a także łatwiejsze wykonanie i utrzymanie, podnoszenie bezpieczeństwa i komfortu użytkowania) czy ekonomicznych (ograniczenie kosztów realizacji, eksploatacji i utrzymania, usprawnienie procesu budowy itd. $)^{15}$. Poszukiwanie innowacyjnych rozwiązań powinno więc dotyczyć tych pozwalających na jak najlepsze wykorzystanie cech nawierzchni nawiązujących do uwarunkowań historycznych oraz na świadome zastosowanie nowych technologii, które jednocześnie umożliwią wyeksponowanie wartości ogrodów i parków publicznych powstałych w poprzednich wiekach. 


\section{NAWIERZCHNIE MINERALNE ORAZ MINERALNO-ŻYWICZNE I ICH ZASTOSOWANIE W HISTORYCZNYCH PARKACH PUBLICZNYCH}

Nawierzchnie mineralne i mineralno-żywiczne, wprowadzane jako innowacyjne rozwiązania, mogą obecnie stanowić rozwiązania alternatywne dla powszechnie stosowanych w wiekach poprzednich nawierzchni ziemnych, zwłaszcza żwirowych, mających opinię niestabilnych i wymagających częstych napraw, przede wszystkim ze względu na fakt, iż pod wpływem długotrwałej wilgoci oraz ruchu ulegają zniszczeniu ${ }^{16}$. Możliwości zastosowania nawierzchni mineralnych uwarunkowane są posiadanymi przez nie określonymi cechami, dzięki którym zyskują przewagę nad poprzednimi w odniesieniu do wielu aspektów ich wykorzystania w historycznych ogrodach i parkach publicznych.

Nawierzchnie mineralne ${ }^{17}$ to takie, które wykonane są na bazie składników naturalnych, m.in. takich jak kamień naturalny, łupki wysokogórskie i inne, są również naturalnie stabilizowane. Dzięki temu zyskują naturalny wygląd, a możliwość doboru neutralnych barw materiałów, z których są wykonane, podkreśla ich walory ozdobne i pozwala na wpisanie w charakter danego miejsca. Zastosowanie wysokiej jakości materiałów naturalnych pozwala na określenie ich jako nawierzchni przyjaznych dla środowiska - całkowicie bezpiecznych i neutralnych. Dotyczy to także ich wodoprzepuszczalności - układane na gruncie rodzimym umożliwiają wsiąkanie wody opadowej w grunt, co pozwala na odciążenie systemu kanalizacji i eliminację efektu gromadzenia się wody na powierzchni. Nawierzchnie mineralne są również odporne na działanie czynników atmosferycznych - są mrozoodporne. Do ich dobrych właściwości należy dodać to, iż nie kruszą się i nie pylą, posiadają wysoką odporność na ciężar, ścieranie i są z reguły niebrudzące. Pozwalają na uzyskanie gładkiej, a jednocześnie stabilnej i bezpiecznej wierzchniej warstwy, zmniejszającej niebezpieczeństwo poślizgu, zapewniającej dostęp dla wózków inwalidzkich. Znacznie ograniczają zarastanie chwastami, eliminują szkodliwe grzyby i patogeny. Są łatwe w układaniu i pielęgnacji, a także generują stosunkowo niskie koszty realizacji.

Nawierzchnie mineralno-żywiczne ${ }^{18}$ charakteryzują się podobnymi cechami - również wykonywane są na bazie składników naturalnych (materiał mineralny), ale zespolonych za pomocą żywicy epoksydowej. W porównaniu z wyżej wymienionymi pozwalają na uzyskanie jeszcze bardziej gładkiej i równej powierzchni, również charakteryzującej się większą trwałością i odpornością na ciężar i ścieranie, ale ich wygląd można pod tym względem ocenić jako mniej naturalny. Posiadają te same cechy kwalifikujące je do grupy nawierzchni przyjaznych dla środowiska. Wymagają jednak odpowiedniej technologii wylewania na miejscu, co podwyższa koszty ich realizacji względem zarówno typowych nawierzchni żwirowych, jak i pozostałych nawierzchni mineralnych.

Oba rodzaje ww. nawierzchni pozwalają na dowolne kształtowanie przebiegu elementów układu drogowego, mogą być także układane przy drzewach i innych roślinach, wspomagając proces ich zasilania w wodę. Ze względu na posiadane cechy, zwłaszcza w odniesieniu do 
naturalnego wyglądu powierzchni oraz kolorystyki wynikającej z zastosowania naturalnych materiałów do ich wykonania, nawierzchnie mineralne w znacznym stopniu nawiązują do charakteru typowych nawierzchni żwirowych. Również pozostałe cechy dodatkowo podnoszą ich wartość, eliminując liczne ograniczenia i utrudnienia w użytkowaniu, generowane przez nawierzchnie zarówno ziemne, jak i żwirowe. Zalety tego rodzaju innowacyjnych rozwiązań mogą być zatem z powodzeniem wykorzystywane w procesie adaptacji i wymiany nawierzchni w historycznych parkach i ogrodach publicznych, odpowiadając współczesnym wymogom ruchu, ale jednak nawiązując pod wieloma względami do cech nawierzchni ogrodowych stosowanych w historii. Świadczyć mogą o tym przykłady wprowadzania nawierzchni mineralnych w rewaloryzacji wielu publicznych założeń ogrodowych o długiej tradycji. Są one stosowane z powodzeniem w obiektach o różnej randze, zwłaszcza w tych będących ważnymi elementami dziedzictwa kulturowego. W przedstawionych niżej przykładach podstawą do wprowadzenia zmian była pozytywna ocena cech nawierzchni mineralnych i mineralno-żywicznych, co znalazło akceptację Stołecznego Konserwatora Zabytków.

Nawierzchnie mineralne zastosowane zostały w układzie drogowym Łazienek Królewskich w Warszawie - letniej rezydencji króla Stanisława Augusta Poniatowskiego, zakładanej w stylu klasycystycznym od 1766 roku $^{19}$, otwartej w późniejszym okresie dla publiczności i przebudowanej na znacznym obszarze w park krajobrazowy. Zmiany wprowadzono w ramach prac rewaloryzacyjnych zainicjowanych w 2010 roku i prowadzonych dla Ogrodu Modernistycznego (il. 3), terenu Hipodromu oraz otoczenia Nowej Oranżerii i fragmentu Alei Chińskiej (il. 4) ${ }^{20}$. Nawierzchniami mineralnymi zastąpiono zużyte nawierzchnie asfaltowe i ziemne, wymieniając także nieatrakcyjne obrzeża betonowe na listwy stalowe, ukrywające granicę nawierzchni i sąsiadujących z nimi powierzchni trawiastych. Innowacyjne rozwiązania dobrze komponują się zarówno w częściach regularnych założenia ogrodowego, jak i obszarach ukształtowanych w sposób krajobrazowy, zapewniając spójność całości kompozycji i podnosząc wartości ozdobne parku. Zabiegi te podwyższyły również komfort poruszania się po drogach parkowych i dostępność obiektu dla osób niepełnosprawnych.

Ogród Saski powstał jako założenie towarzyszące barokowej rezydencji królewskiej (Pałacowi Saskiemu), tworzonej dla Augusta II Mocnego od 1713 roku przez kolejne 40 lat jako część założenia urbanistycznego Osi Saskiej ${ }^{21}$. W 1727 roku został - jako pierwszy obiekt na terenie ziem polskich - otwarty dla publiczności. W latach 1816-1827 został przekształcony według projektu Jamesa Savage’a - zachowano biegnącą centralnie oś główną, a części boczne ukształtowano swobodnie. Zniszczenia II wojny światowej oraz zmniejszenie powierzchni parku po jej zakończeniu wpłynęły destrukcyjnie na kompozycję całego założenia. W kolejnych latach dokonano dalszych przekształceń układu drogowego i nawierzchni - aleję główną i część bocznych wylano asfaltem, na pozostałych wprowadzono nawierzchnię żwirową, a powstające przedepty wykładano m.in. płytami betonowymi. W 2012 roku przeprowadzono remont nawierzchni w otoczeniu fontanny, wprowadzając charakterystyczny rysunek wykonany z kostki betonowej i nawierzchni żwirowej - nowe elementy nie związane 
z historycznym układem parku. W 2014 roku zakończono wymianę nawierzchni na mineralną, wzmocnioną obrzeżami betonowymi (il. 5), w części północnej i południowej założenia. Zmiana ta korzystnie wpłynęła na wizualny odbiór bocznych części parku i zapewniła większą ich dostępność dla pieszych. Rodzaj zastosowanych obrzeży nie pozwolił jednak na precyzyjne wyprofilowanie łuków, po których prowadzone są ścieżki, co wyraźnie widoczne jest w niektórych fragmentach układu drogowego.

Zmiany w zakresie wymiany nawierzchni wprowadzono także w warszawskim Ogrodzie Krasińskich, powstałym jako założenie pałacowo-ogrodowe w stylu francuskim, stworzone według projektu Tylmana z Gameren w latach 70. XVII wieku ${ }^{22}$ dla Jana Dobrogosta Krasińskiego. Po odkupieniu założenia przez Komisję Skarbu Koronnego i przebudowie ogrodu w 1768 roku został on otwarty do użytku publicznego. W latach 1891-1895 został przekształcony w park krajobrazowy według projektu Franciszka Szaniora ${ }^{23}$, który to układ przetrwał do połowy XX wieku. Po II wojnie światowej dokonano restauracji parku, wzorując się na planach Szaniora, powiększono teren obiektu w części północnej i południowej. Wprowadzono jednak na znacznej części układu drogowego nawierzchnie asfaltowe, obce dla ogrodu, a w kolejnych latach w wybranych miejscach także płyty betonowe i żwir. W 2011 roku przeprowadzono konkurs na rewaloryzację całości założenia, która realizowana była w latach 2012-2014. W części historycznej ogrodu wprowadzono piesze nawierzchnie mineralne z grysu kwarcytowego (il. 6) z obrzeżem z kątownika stalowego ${ }^{24}$. Drogi w części południowej - współcześnie dodanej do parku - zyskały nawierzchnię mineralno-żywiczną (il. 7) z obrzeżem betonowym oblewanym. Wprowadzenie tej nawierzchni, dającej możliwość bardziej intensywnego wykorzystania, dopasowane zostało do rozbudowanego programu parku, którego kumulacja nastąpiła właśnie w tej części. Wymiana nawierzchni podniosła w znacznym stopniu walory ozdobne i funkcjonalne ogrodu.

Reprezentacyjny park publiczny Warszawy - Park Ujazdowski - zaprojektowany przez Franciszka Szaniora, został otwarty dla publiczności w 1896 roku i bardzo szybko zyskał miano „salonu letniego stolicy”25. W pierwotnej wersji posiadał na znacznym obszarze nawierzchnie ziemne, zmieniane stopniowo na żwirowe. Te ostatnie zostały poprawione na znacznym obszarze w 2002 roku, kiedy zakończono kompleksową rewaloryzację założenia. Część placów w otoczeniu wejść do parku oraz kameralne placyki wypoczynkowe zostały wyłożone nawierzchnią z kostki granitowej stanowiącej nowy materiał w parku. Po kilkunastu latach użytkowania znaczna część nawierzchni żwirowych uległa zniszczeniu, łącznie z elementami towarzyszących im obrzeży drewnianych. W 2015 roku wymieniono te nawierzchnie na mineralne, naturalnie stabilizowane (il. 8) - w obrębie głównej alei obwodnicowej zyskały obrzeża w formie wąskiego pasa z kostki granitowej (jako nawiązanie do materiału zastosowanego na placach), na pozostałych fragmentach wprowadzono listwę stalową. W centralnej części parku, w otoczeniu salonu ogrodowego i pomnika I. Paderewskiego, zachowano obrzeża kamienne. Zmiany nawierzchni pozwoliły na podwyższenie komfortu korzystania ze ścieżek parkowych i dostępności parku, w tym dla osób niepełnosprawnych, podniosły także 
walory estetyczne obiektu, gdyż neutralna kolorystyka zastosowanego materiału dobrze komponuje się z jego charakterem i nawiązuje do uwarunkowań historycznych. Niezgodne z formą pierwotną pozostają nadal fragmenty wyłożone kostką, a pewien dysonans budzić może zastosowanie różnych rodzajów obrzeży, których łączenie nie w każdym miejscu zostało precyzyjnie wykonane.

\section{PODSUMOWANIE I WNIOSKI}

Historyczne ogrody i parki publiczne, jako grupa założeń ogrodowych podlegających intensywnym przemianom w kolejnych latach ich istnienia przede wszystkim na skutek uwarunkowań społecznych, wymaga wyjątkowego podejścia w zakresie ich adaptacji do nowych funkcji. Należy uznać i docenić tę formę przemian, uwarunkowanych historycznie, jako element charakterystyczny złożonego procesu, jakiemu na przestrzeni wieków poddawana jest ta grupa obiektów. Kierunek adaptacji, uwzględniający dostosowanie nawierzchni do nowych potrzeb, jak wspomniano w treści niniejszej publikacji, decyduje o ciągłości istnienia tych założeń ogrodowych i jest w wielu przypadkach podstawą umożliwiającą ich przetrwanie do czasów obecnych, ale także „ożywienia”, gdy popadają w zapomnienie i ulegają destrukcji. Jednocześnie - w przypadku parków publicznych sięgających swym rodowodem XIX wieku lub nawet okresów wcześniejszych - dbałość o utrzymanie ich wartości zabytkowych, historycznych, kulturowych, ale także społecznych jest zadaniem priorytetowym. Korzystanie z innowacyjnych rozwiązań w zakresie ich adaptacji do nowych funkcji, w tym przypadku przy wykorzystaniu nowych rodzajów nawierzchni, stanowi zatem kolejny etap ich rozwoju. Zastosowanie innowacyjnych technik i technologii powinno wspierać ten złożony proces adaptacji, a zakres wprowadzanych zmian nie może wpływać na degradację dotychczasowych wartości tych obiektów, ale dodawać nowe z poszanowaniem tych pierwszych.

Wśród pozytywnych aspektów stosowania nawierzchni mineralnych (także mineralno-żywicznych) w historycznych ogrodach i parkach publicznych wymienić należy ich walory:

- funkcjonalne - związane z łatwością ich dostosowania do warunków terenowych oraz historycznego przebiegu dróg, zmniejszeniem niebezpieczeństwa poślizgu, podwyższeniem komfortu poruszania się i dostępności dla użytkowników, w tym ułatwień w zakresie poruszania się przez osoby niepełnosprawne;

- techniczne i ekonomiczne - realizowane przez pozytywny wpływ na odciążenie kanalizacji deszczowej i zmniejszenie kosztów odprowadzania wody, możliwość zbliżenia do roślin (np. starych drzew), ograniczając negatywne skutki ingerencji w podłoże i system korzeniowy, ograniczenie kosztów utrzymania i konserwacji w systemie wieloletnim; 
- estetyczne - przez znaczący udział w utrzymaniu tradycyjnego charakteru obiektów, podnoszenie ich atrakcyjności wizualnej dzięki znacznemu nawiązaniu do cech materiałów stosowanych w historii, a przez to ograniczenie poczucia utraty autentyczności obiektu, wynikającego z przemian dokonywanych w kolejnych dekadach;

- $\quad$ przyrodnicze - uwarunkowane proekologicznymi właściwościami nawierzchni, mającymi udział w retencjonowaniu wód opadowych, tworzeniu nietoksycznego podłoża dla środowiska (nieszkodliwego dla wód gruntowych i roślin), zwiększaniu dostępu wody i powietrza do korzeni roślin rosnących blisko nawierzchni, a nawet możliwości wykorzystania znacznych części nawierzchni w procesie recyklingu.

Gwarancją uzyskania pozytywnego efektu końcowego w stosowaniu nawierzchni mineralnych i mineralno-żywicznych jako alternatywy dla ziemnych i żwirowych jest nie tylko odpowiednie dopasowanie materiału (jego rodzaju, koloru czy faktury) do indywidualnych cech danego ogrodu lub parku publicznego, które oparte powinno być w każdym z przypadków o wiele szczegółowych analiz ${ }^{26}$. Umożliwi to również wysoki standard wykonania nawierzchni i ich właściwe dostosowanie do rodzaju ruchu, jak i odpowiednio prowadzone zabiegi konserwacyjne w kolejnych latach użytkowania. Niespełnienie tych wymogów będzie przyczyną zmian o charakterze negatywnym. 

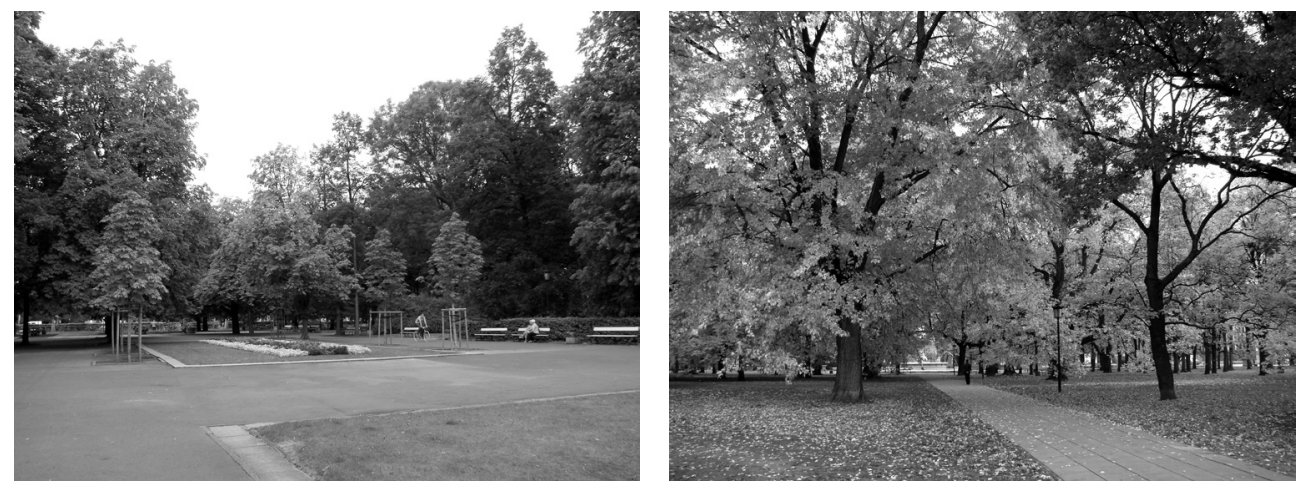

II. 1. Ogród Saski w Warszawie: a) nawierzchnia asfaltowa alei głównej (fot. K. Kimic 2016),

b) nawierzchnia z płyt betonowych w alei bocznej (fot. K. Kimic 2015)

III. 1. Saxon Garden in Warsaw: a) asphalt pavement placed in main alley,

b) concrete plates placed in side alley
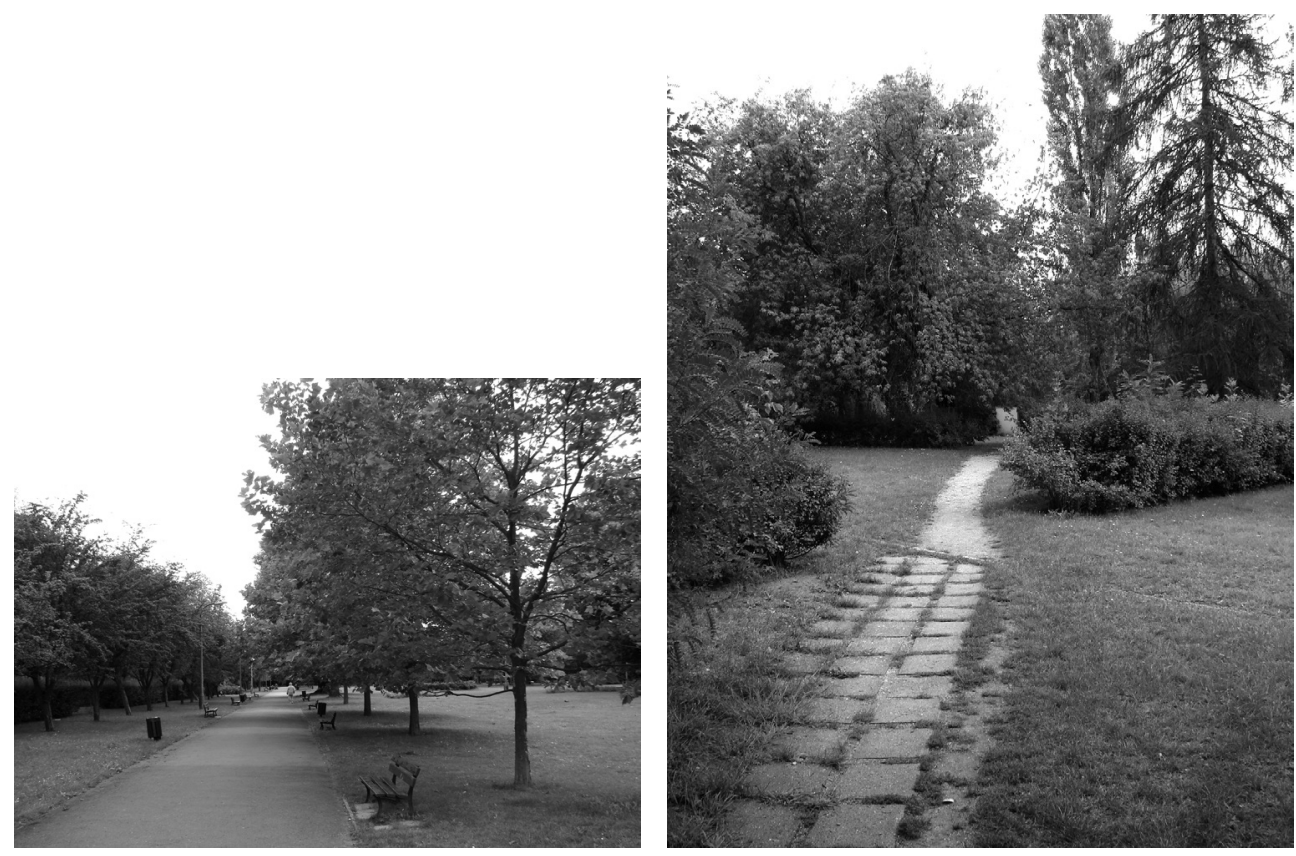

II. 2. Park im. gen. J. Sowińskiego w Warszawie: a) nawierzchnia asfaltowa alei głównej (fot. K. Kimic 2016), b) różnorodne nawierzchnie w strefie dawnych ogrodów rodzajowych (fot. K. Kimic 2016)

III. 2. Gen. J. Sowiński Park in Warsaw: a) asphalt pavement placed in main alley, b) different types of pavement in former thematic gardens 

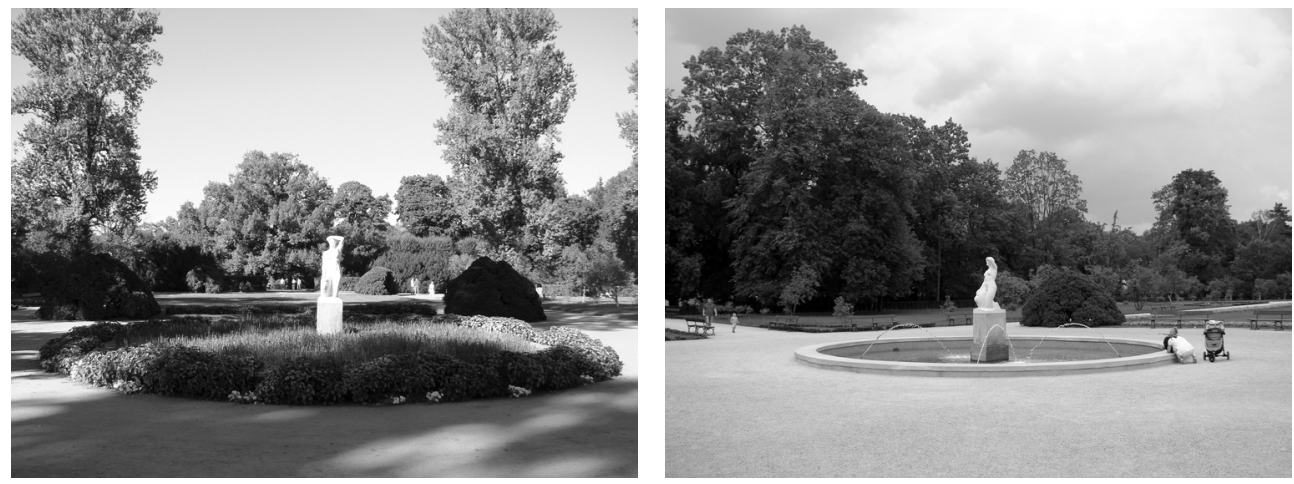

II. 3. Ogród Modernistyczny w Łazienkach Królewskich w Warszawie: a) nawierzchnia żwirowa przed zmianami (fot. K. Kimic 2014), b) wodoprzepuszczalna nawierzchnia mineralna wprowadzona w ramach rewitalizacji (fot. K. Kimic 2016)

III. 3. Modern Garden in Łazienki Królewskie Park, Warsaw: a) old gravel pavement before changes, b) water-permeable mineral aggregate pavement applied during revitalization process
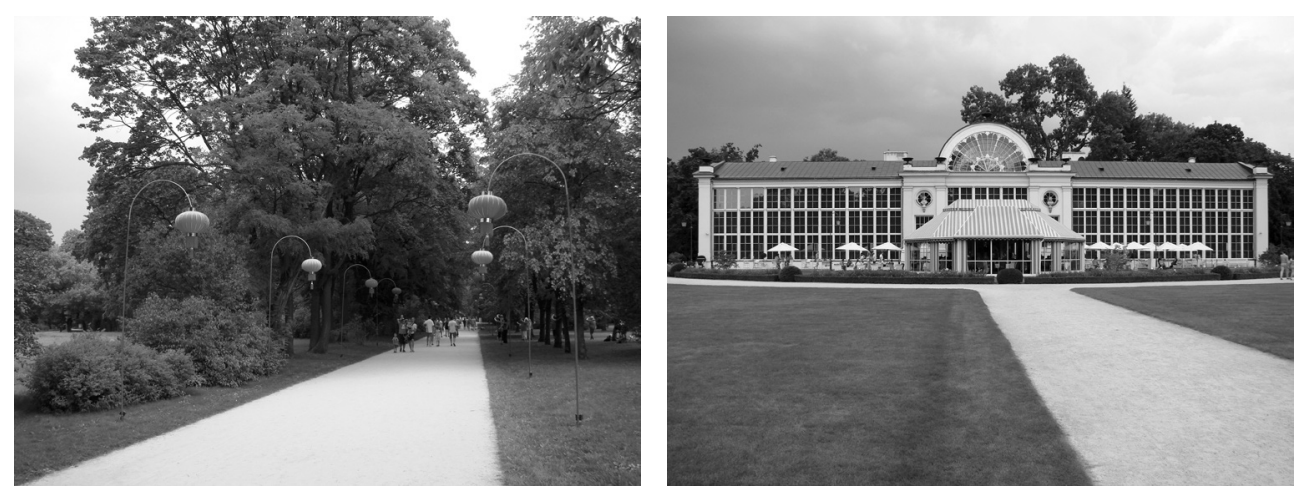

II. 4. Łazienki Królewskie w Warszawie - wodoprzepuszczalna nawierzchnia mineralna wprowadzona w reprezentacyjnych częściach parku: a) Aleja Chińska (fot. K. Kimic 2016), b) otoczenie Nowej

Oranżerii (fot. K. Kimic 2016)

III. 4. Łazienki Królewskie Park in Warsaw - water-permeable mineral aggregate pavement applied to representative parts of park: a) Chinese Alley, b) surroundings of the New Orangery 

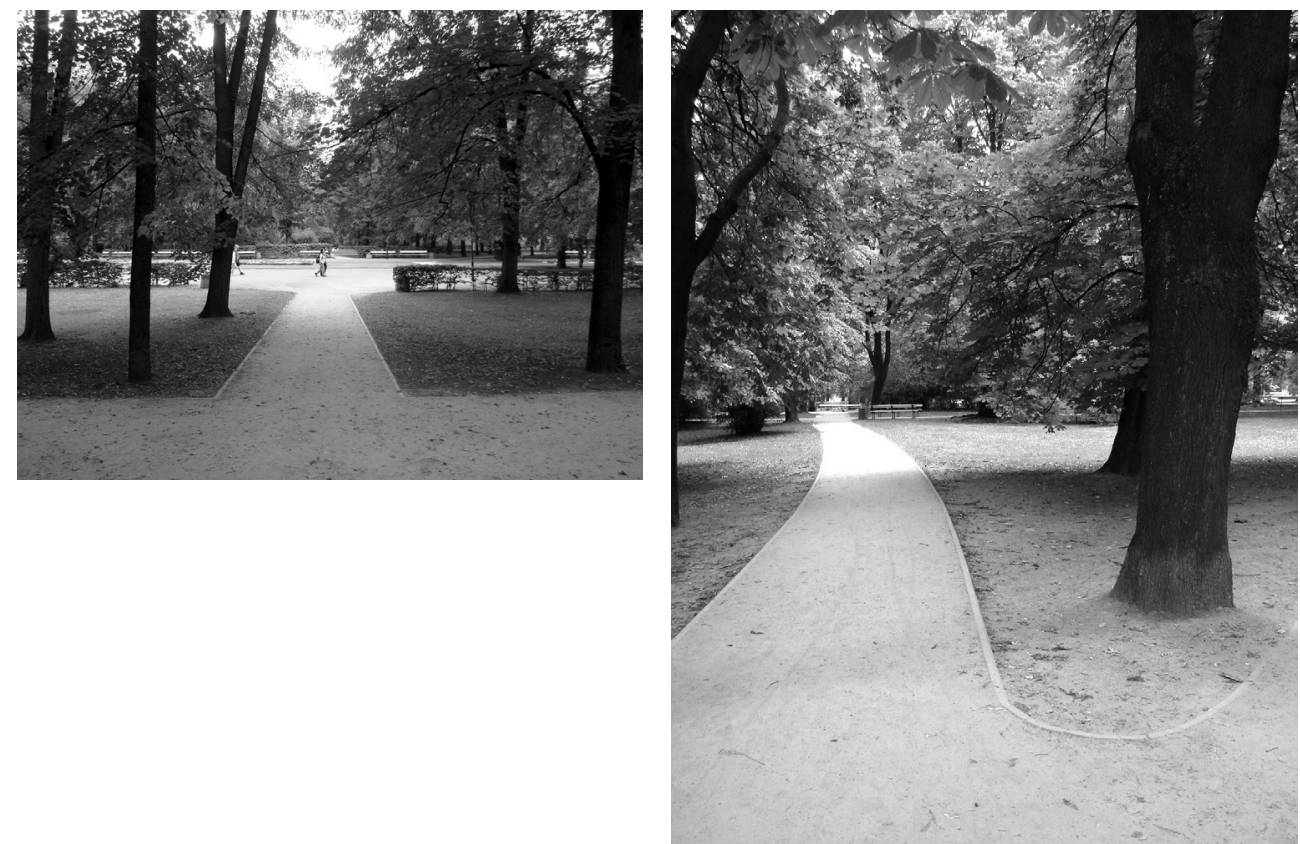

II. 5. Ogród Saski w Warszawie - nawierzchnie żwirowe wymienione na wodoprzepuszczalne nawierzchnie mineralne: a) północna część ogrodu (fot. K. Kimic 2016), b) południowa część ogrodu (fot. K. Kimic 2016)

III. 5. Saxon Garden in Warsaw - gravel replaced by water-permeable mineral aggregate pavement: a) north part of garden, b) south part of garden 

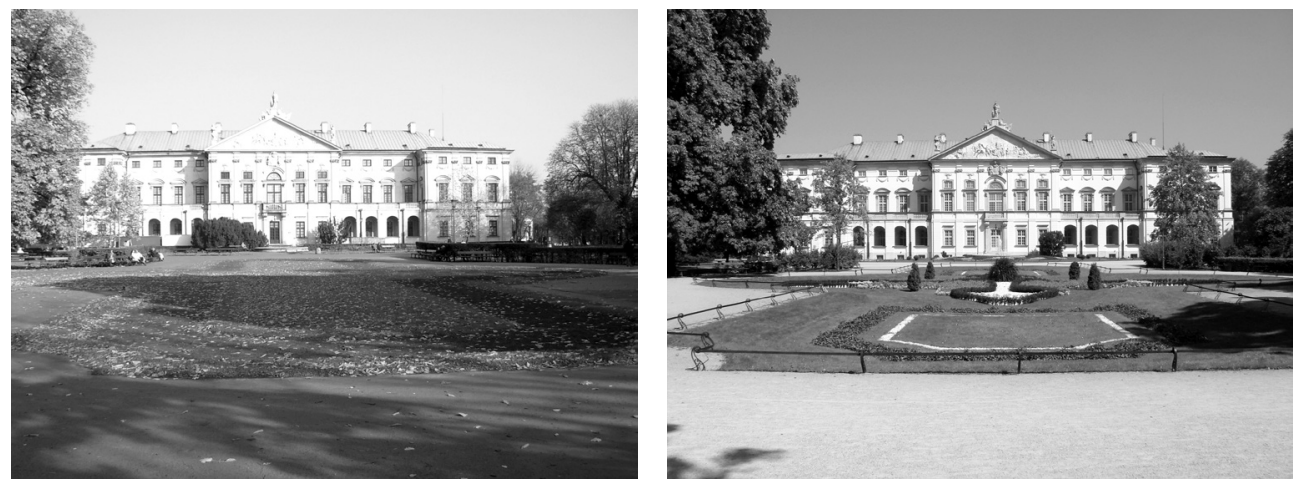

II. 6. Ogród Krasińskich w Warszawie - widok pałacu od strony ogrodu: a) nawierzchnia asfaltowa przed zmianami (fot. K. Kimic 2010), b) wodoprzepuszczalna nawierzchnia mineralna po zmianach

(fot. K. Kimic 2016)

III. 6. Krasińskich Garden in Warsaw - a view of palace from the garden: a) asphalt pavement before changes, b) water-permeable mineral aggregate pavement after changes
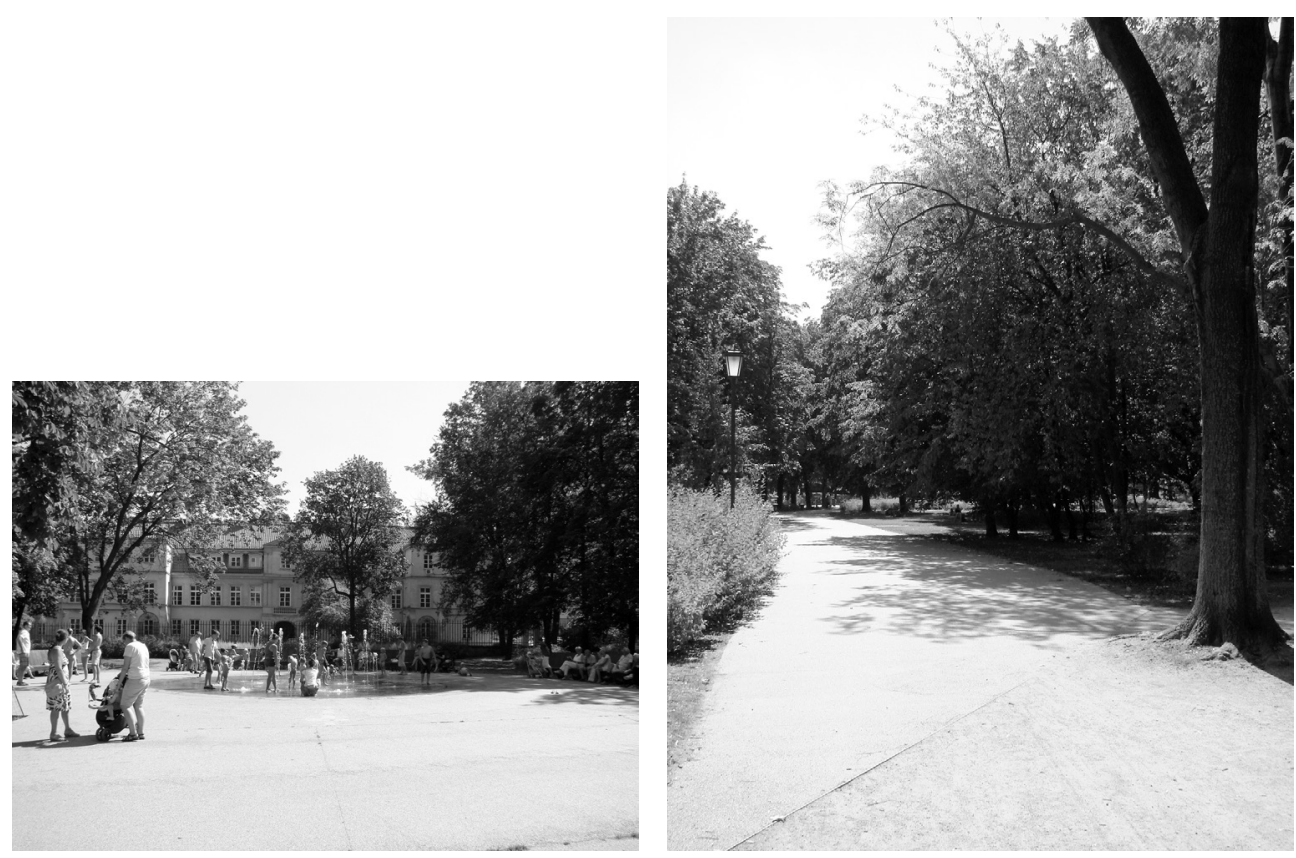

II. 7. Ogród Krasińskich w Warszawie - wodoprzepuszczalna nawierzchnia mineralno-żywiczna zastosowana w bocznej części ogrodu: a) Plac Wodny (fot. K. Kimic 2016), b) aleja (fot. K. Kimic 2016)

III. 7. Krasińskich Garden in Warsaw - water-permeable resinous pavement applied to side part of the garden: a) Water Plaza, b) side alley 

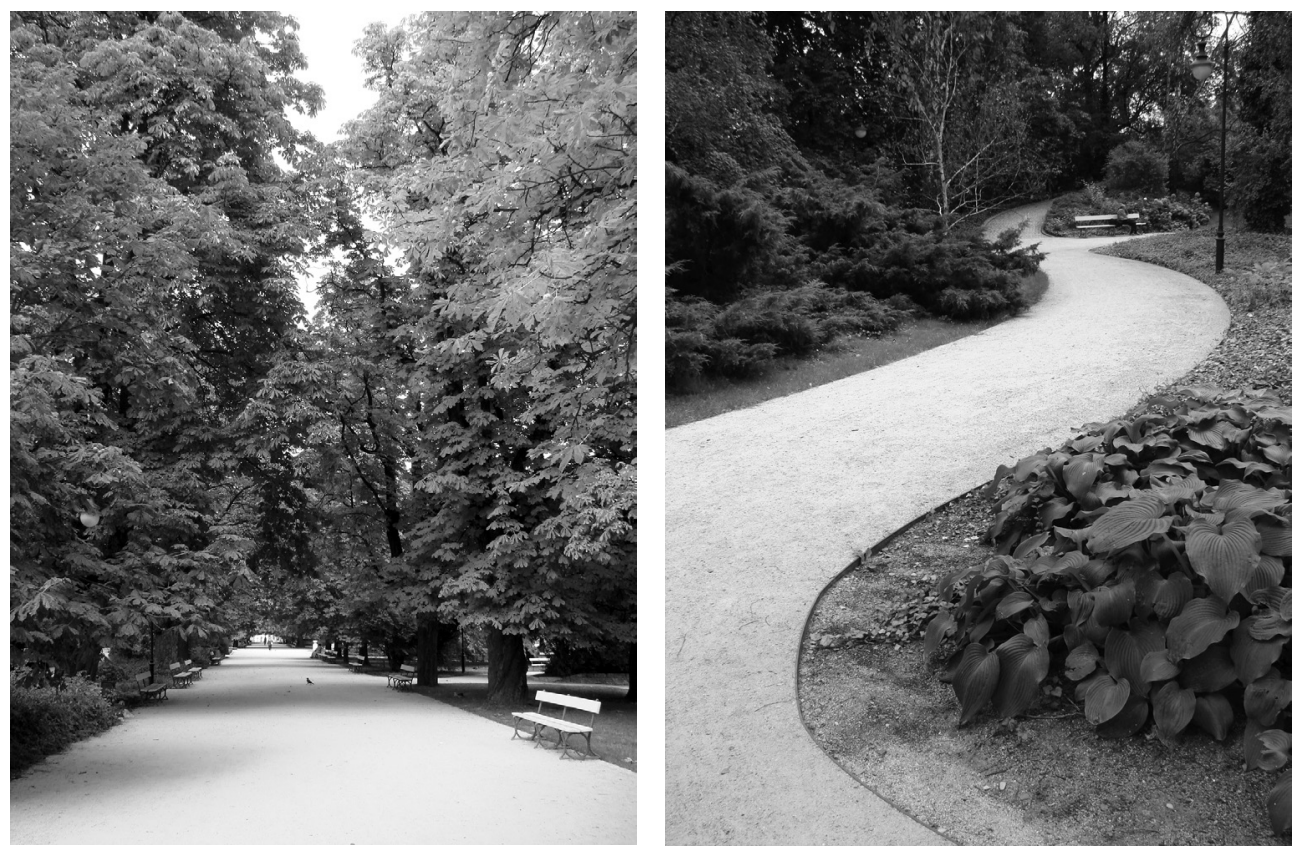

II. 8. Park Ujazdowski w Warszawie - wodoprzepuszczalna nawierzchnia mineralna zastosowana na drogach parkowych: a) Aleja Kasztanowcowa (fot. K. Kimic 2016), b) boczna alejka parkowa (fot. K. Kimic 2016)

III. 8. Ujazdowski Park in Warsaw - water-permeable mineral aggregate pavement applied to park alleys: a) Chestnut Tree Alley, b) side alley 


\section{PRZYPISY}

1 K. Kimic, Miejsce i rola architektury w parkach publicznych XIX wieku, [w:] Architektura ogrodowa-obiekty architektoniczne w kompozycjach ogrodowych - historia i współczesność, Mitkowska A., Mirek Z., Hodor K. (red.), XIV Konferencja Naukowa z cyklu Sztuki Ogrodowej i Dendrologii Historycznej, 8-9 listopada 2007, Kraków 2007, s. 64-65.

2 L. Majdecki, Ochrona i konserwacja zabytkowych założeń ogrodowych, Wydawnictwo Naukowe PWN, Warszawa 1993, s. 313.

3 B. Furmanik, Dobory materiałowe w ogrodach zabytkowych, „Kurier Konserwatorski”, nr 7, 2010, s. 27.

4 B. Kozińska, B. Makowska, Zabytkowe nawierzchnie ulic w Szczecinie, „Ochrona Zabytków”, nr 1, 2006, s. 55.

5 J. Duda, To też sq zabytki... Nawierzchnie, „Spotkania z zabytkami”, nr 2, 1987, s. 30.

6 L. Majdecki, Drogi parkowe, „Drogownictwo”, z. 11, 1968, s. 265.

7 L. Majdecki, Ochrona i konserwacja..., op. cit.

8 Art. 4. Karty Florenckiej mówi, iż Autentyczność ogrodu historycznego dotyczy w jednakowej mierze jego rysunku i wielkości poszczególnych jego części, jak i jego dekoracji, wyboru roślin lub minerałów, z których się składa", Międzynarodowa Karta Ogrodów IFLA-ICOMOS (Karta Florencka), Florencja 1981, http://www.nid.pl/upload/iblock/9b1/9b13bc019894c 7975620590ae56f9641.pdf (dostęp: 10.09.2016).

9 J. Duda, op. cit., s. 26-30; Majdecki L., Ochrona i konserwacja..., op. cit., s. 305, 311. Zasoby zabytków drogownictwa obejmują zarówno drogi, jak i ich nawierzchnie, na co szczególną uwagę zwracały już w latach 60. XX wieku służby ochrony zabytków drogownictwa m.in. w zapisach ustawy z 1962 r. O ochronie dóbr kultury i o muzeach. Filippoto W., To też sq zabytki... Drogi, „Spotkania z zabytkami”, nr 6, 1981, s. 41.

10 L. Majdecki, Ochrona i konserwacja..., op. cit., s. 311; J. Duda, Funkcje i znaczenie utwardzania nawierzchni w terenach zabudowanych, „Geologia”, Tom 35, Zeszyt 1, 2009, s. 30.

${ }^{11}$ L. Majdecki, Historia ogrodów, tom 1: Od starożytności po barok, Wydawnictwo Naukowe PWN, Warszawa 2008, s. 13.

12 L. Majdecki, Ochrona i konserwacja..., op. cit., s. 310.

13 Ibidem, s. 305.

14 J. Bogdanowski, Polskie ogrody ozdobne, Arkady, Warszawa 2000, s. 225.

15 L. Majdecki, Drogi parkowe..., op. cit., s. 262.

${ }^{16}$ L. Majdecki, Ochrona i konserwacja..., op. cit., s. 313.

${ }_{17}$ GreenCityLife - Technologie dla krajobrazu, http://gcl.com.pl/ (dostęp: 14.08.2016); Nawierzchnie mineralne firmy tegra, http://www.nawierzchniemineralne.pl/ (dostęp: 14.08.2016); HanseGrand, http://hansegrand.pl/ (dostęp: 16.08.2016).

${ }^{18}$ N. Pocheć, A. Wójcik, Możliwości zastosowania nowoczesnych materiałów budowlanych przy rewaloryzacji ogrodów historycznych, „Przestrzeń i Forma”, nr 19, 2013, s. 292; Terra- 
Way, nawierzchnie wodoprzepuszczalne, http://www.terraway.pl/terraway_dlaczego.html (dostęp: 11.09.2016).

19 L. Majdecki, Historia ogrodów, tom 2: Od XVIII wieku do współczesności, Wydawnictwo Naukowe PWN, Warszawa 2009, s. 199.

${ }^{20}$ E. Bartman, P. Bartman, Koncepcja Rewaloryzacji Otoczenia Nowej Oranżerii, Ogrodu Modernistycznego, Terenu Hipodromu, Fragmentu Alei Chińskiej (Drogi Wilanowskiej), opracowanie wykonane dla Muzeum Łazienki Królewskie w Warszawie, Warszawa 2012.

${ }^{21}$ L. Majdecki, Historia ogrodów, tom 2, op. cit., s. 435.

22 Istnieją pewne rozbieżności co do daty powstania założenia - rok 1676 za: Zug Sz.B., Ogrody w Warszawie i jej okolicach opisane w 1794 roku, Warszawa 1848; rok 1677 za: Majdecki L., Historia ogrodów, tom 1, op. cit., s. 448; rok 1692 za: Ogród Krasiński (z planem), „Ogrodnik Polski", nr 18, 1893, s. 409.

${ }^{23}$ Ogród Krasiński..., op. cit., s. 410.

${ }^{24}$ Według dokumentacji projektowej: Projekt modernizacji-rewaloryzacji Ogrodu Krasińskich w Warszawie, Faza - Projekt wykonawczy, Przekroje nawierzchni, Abies - Architektura Krajobrazu, Warszawa 2012, http://www.ztp.waw.pl/media/2013/02/12/o_kras_przekroje_naw_przekroje_6_2.pdf (dostęp: 21.10.2016).

25 A. Zaleski, Z Komitetu Plantacyjnego M. R., „Ogrodnik Polski”, nr 7, 1930, s. 135.

${ }^{26}$ W. Grzybowska, Nawierzchnie w obszarach zabytkowych [w:], Sanetra P. (red.), Projektowanie i budowa dróg. Teoria i praktyka, Krajowa Konferencja Naukowo-Techniczna, Kazimierz Dolny, 7-8 października 1999, Stowarzyszenie Inżynierów i Techników Komunikacji, Zarząd Oddziału w Lublinie, Wydawnictwo Norbertinum, Lublin 1999, s. 311-320.

\section{BIBLIOGRAFIA}

Bartman E., Bartman P., Koncepcja Rewaloryzacji Otoczenia Nowej Oranżerii, Ogrodu Modernistycznego, Terenu Hipodromu, Fragmentu Alei Chińskiej (Drogi Wilanowskiej), opracowanie wykonane dla Muzeum Łazienki Królewskie w Warszawie, Warszawa 2012.

Bogdanowski J., Polskie ogrody ozdobne, Arkady, Warszawa 2000.

Duda J., Funkcje i znaczenie utwardzania nawierzchni w terenach zabudowanych, „Geologia”, Tom 35, Zeszyt 1, 2009, s. 29-39.

Duda J., To też sq zabytki... Nawierzchnie, „Spotkania z zabytkami”, nr 2, 1987, s. 26-30.

Filippoto W., To też sq zabytki... Drogi, „Spotkania z zabytkami”, nr 6, 1981, s. 38-41.

GreenCityLife - Technologie dla krajobrazu, dostępny w Internecie, http://gcl.com.pl/ (dostęp: 14.08.2016).

Grzybowska W., Nawierzchnie w obszarach zabytkowych, [w:] Sanetra P. (red.), Projektowanie i budowa dróg. Teoria i praktyka, Krajowa Konferencja Naukowo-Techniczna, Kazimierz 
Dolny, 7-8 października 1999, Stowarzyszenie Inżynierów i Techników Komunikacji, Zarząd Oddziału w Lublinie, Wydawnictwo Norbertinum, Lublin 1999, s. 311-320.

HanseGrand, http://hansegrand.pl/ (dostęp: 16.08.2016).

Kimic K., Miejsce i rola architektury w parkach publicznych XIX wieku, [w:] Mitkowska A., Mirek Z., Hodor K. (red.), Architektura ogrodowa - obiekty architektoniczne w kompozycjach ogrodowych - historia i współczesność, XIV Konferencja Naukowa z cyklu Sztuki Ogrodowej i Dendrologii Historycznej, 8-9 listopada 2007, Kraków 2007, s. 63-72.

Kozińska B., Makowska B., Zabytkowe nawierzchnie ulic w Szczecinie, „Ochrona Zabytków”, nr 1, 2006, s. 52-72.

Majdecki L., Drogi parkowe, „Drogownictwo”, z. 11, 1968, s. 261-266.

Majdecki L., Historia ogrodów, tom 1: Od starożytności po barok, Wydawnictwo Naukowe PWN, Warszawa 2008.

Majdecki L., Historia ogrodów, tom 2: Od XVIII wieku do współczesności, Wydawnictwo Naukowe PWN, Warszawa 2009.

Majdecki L., Ochrona i konserwacja zabytkowych założeń ogrodowych, Wydawnictwo Naukowe PWN, Warszawa 1993.

Międzynarodowa Karta Ogrodów IFLA-ICOMOS (Karta Florencka), Florencja 1981, http:// www.nid.pl/upload/iblock/9b1/9b13bc019894c7975620590ae56f9641.pdf (dostęp: 10.09.2016).

Nawierzchnie mineralne firmy tegra, http://www.nawierzchniemineralne.pl/ (dostęp: 14.08.2016).

Ogród Krasiński (z planem), „Ogrodnik Polski”, nr 18, 1893, s. 409-411.

Pocheć N., Wójcik A., Możliwości zastosowania nowoczesnych materiałów budowlanych przy rewaloryzacji ogrodów historycznych, „Przestrzeń i Forma”, nr 19, 2013, s. 289-300.

Projekt modernizacji - rewaloryzacji Ogrodu Krasińskich w Warszawie, Faza - Projekt wykonawczy, Przekroje nawierzchni, Abies - Architektura Krajobrazu, Warszawa 2012, http:// www.ztp.waw.pl/media/2013/02/12/o_kras_przekroje_naw_przekroje_6_2.pdf (dostęp: 21.10.2016).

TerraWay, nawierzchnie wodoprzepuszczalne, http://www.terraway.pl/terraway_dlaczego. html (dostęp: 11.09.2016).

Zaleski A., Z Komitetu Plantacyjnego M. R., „Ogrodnik Polski”, nr 7, 1930, s. 135.

Zug Sz.B., Ogrody w Warszawie i jej okolicach opisane w 1794 roku, Warszawa 1848. 